\title{
MRI-based identification of undifferentiated cells: looking at the two faces of Janus
}

This article was published in the following Dove Press journal:

International Journal of Nanomedicine

II February 2014

Number of times this article has been viewed

\author{
Ciprian Tomuleasa ${ }^{1,2}$ \\ Ioan Stefan Florian ${ }^{3}$ \\ Cristian Berce ${ }^{4}$ \\ Alexandru Irimie ${ }^{5,6}$ \\ loana Berindan-Neagoe ${ }^{2,7,9}$ \\ Andrei Cucuianu' ${ }^{1,8}$ \\ 'Department of Hematology, Ion \\ Chiricuta Cancer Center, Cluj \\ Napoca, Romania; ${ }^{2}$ Research Center \\ for Functional Genomics and \\ Translational Medicine, luliu Hatieganu \\ University of Medicine and Pharmacy, \\ Cluj Napoca, Romania; ${ }^{3}$ Department \\ of Neurosurgery, ${ }^{4}$ Animal Facility, luliu \\ Hatieganu University of Medicine \\ and Pharmacy, Cluj Napoca, Romania; \\ ${ }^{5}$ Department of Surgery, Ion Chiricuta \\ Cancer Center, Cluj Napoca, Romania; \\ ${ }^{6}$ Department of Oncology, luliu \\ Hatieganu University of Medicine \\ and Pharmacy, Cluj Napoca, Romania; \\ ${ }^{7}$ Department of Functional Genomics, \\ The Oncology Institute Ion Chiricuta, \\ Cluj Napoca, Romania; ${ }^{8}$ Department \\ of Hematology, ${ }^{9}$ Department \\ of Immunology, luliu Hatieganu \\ University of Medicine and Pharmacy, \\ Cluj Napoca, Romania
}

Correspondence: Ciprian Tomuleasa Ion Chiricuta Cancer Center, Bulevardul 2I Decembrie Nr 73, 400 I24, Cluj Napoca, Romania Email ciprian.tomuleasa@umfcluj.ro

\section{Dear editor}

We have read with great interest the paper of Ketkar-Atre et al, ${ }^{1}$ in which they have developed a new way of tracking stem cells after transplantation using a magnetic resonance imaging (MRI)-based method. They have proven using high resolution electron microscopy that various types of undifferentiated cells, also known as stem cells, have a differentiation uptake of iron oxide nanoparticles according to their size and proliferation rate. Due to its super-paramagnetic properties, iron oxide is slowly finding its way from the laboratory to the clinic. When combined with MRI, it can very efficiently track a stem cell in vivo, as in the case of autologous transplantation, ${ }^{2,3}$ but also for other conditions such as Duchenne muscular dystrophy.

Undifferentiated cells are slowly changing the way we treat various diseases and transplantation is currently the standard-of-care in hematology and ophthalmology, but these cells are not always the solution for therapy. Sometimes, undifferentiated cells are the cause of disease initiation, progression and resistance to therapy. This is the case of stem-like cells, that have been isolated from a wide variety of malignancies ${ }^{4-6}$ and have been proven to be responsible for resistance to both chemotherapy and radiation oncology treatment. This most often leads to a dismal prognosis for the patient. Various nanotechnology-based approaches have been developed to specifically target these stem-like cells, ${ }^{7,8}$ but so far little real progress has been made in the clinic because of late diagnosis of malignancy relapse.

Using iron oxide nanoparticles combined with an MRI or positron emission tomography (PET) scan, we may actually identify a very small cluster of stem-like malignant cells and diagnose a tumor relapse before clinical, or preclinical investigations show it. This method has already been published by Marotta et al, ${ }^{9}$ but further investigation must be carried out in the field.

\section{Disclosure}

The authors report no conflicts of interest in this communication.

\section{References}

1. Ketkar-Atre A, Struys T, Soenen SJ, et al. Variability in contrast agent uptake by different but similar stem cell types. Int J Nanomedicine. 2013;8(1):4577-4591.

2. Khurana A, Chapelin F, Beck G, et al. Iron administration before stem cell harvest enables MR imaging tracking after transplantation. Radiology. 2013;269(1):186-197. 
3. Odintsov B, Chun JL, Berry SE. Whole body MRI and fluorescent microscopy for detection of stem cells labeled with superparamagnetic iron oxide (SPIO) nanoparticles and DiI following intramuscular and systemic delivery. Methods Mol Biol. 2013;1052:1-17.

4. Florian IS, Tomuleasa C, Soritau O, et al. Cancer stem cells and malignant gliomas. From pathophysiology to targeted molecular therapy. J BUON. 2011;16(1):16-23.

5. Tomuleasa C, Soritau O, Rus-Ciuca D, et al. Functional and molecular characterization of glioblastoma multiforme-derived cancer stem cells. J BUON. 2010;15(3):583-591.

6. Tomuleasa C, Soritau O, Rus-Ciuca D, et al. Isolation and characterization of hepatic cancer cells with stem-like properties from hepatocellular carcinoma. J Gastrointestin Liver Dis. 2010;19(1):61-67.
7. Orza A, Soritau O, Tomuleasa C, et al. Reversing chemoresistance of malignant glioma stem cells using gold nanoparticles. Int J Nanomedicine. 2013;8:689-702.

8. Tomuleasa C, Soritau O, Orza A, et al. Gold nanoparticles conjugated with cisplatin/doxorubicin/capecitabine lower the chemoresistance of hepatocellular carcinoma-derived cancer cells. J Gastrointestin Liver Dis. 2012;21(2):187-196.

9. Marotta R, Falqui A, Curcio A, Quarta A, Pellegrino T. Immunocytochemistry, electron tomography, and energy dispersive X-ray spectroscopy (EDXS) on cryosections of human cancer cells doped with stimuli responsive polymeric nanogels loaded with iron oxide nanoparticles. Methods Mol Biol. 2013;1025:179-198.

\section{Publish your work in this journal}

The International Journal of Nanomedicine is an international, peerreviewed journal focusing on the application of nanotechnology in diagnostics, therapeutics, and drug delivery systems throughout the biomedical field. This journal is indexed on PubMed Central, MedLine, CAS, SciSearch $\AA$, Current Contents ${ }^{\circledR} /$ Clinical Medicine,
Journal Citation Reports/Science Edition, EMBase, Scopus and the Elsevier Bibliographic databases. The manuscript management system is completely online and includes a very quick and fair peer-review system, which is all easy to use. Visit http://www.dovepress.com/ testimonials.php to read real quotes from published authors. 